\title{
EFFECTS OF DIFFERENT TYPES OF FEED ON GROWTH, SURVIVAL AND DIGESTIVE ENZYME ACTIVITY OF EARLY JUVENILE-STAGE MARBLE GOBY, Oxyeleotris marmoratus
}

\author{
Muhammad Darwis*), Sitti Raehana Muhd. Shaleh*), Masaru Tanaka*), \\ and Shigeharu Senoo*)
}

\begin{abstract}
The stable mass seed production technique of marble goby, Oxyeleotris marmoratus has not yet been established due to high mortality occurring on the early juvenile stage and/or after 40 days after hatching $(\mathrm{d} \mathrm{AH})$. In order to establish the mass seed production technique, $O$. marmoratus juveniles of $40 \mathrm{~d}$ AH were reared for 60 days to determine growth, survival and digestive enzyme activity at different types of feed (trash fish, artificial feed and Artemia sp. nauplii). Specific growth rate (5.32) and survival rate (91.3\%) in juveniles fed Artemia sp. nauplii showed significantly higher $(P<0.05)$ than those of juveniles fed trash fish and artificial feed. At the end of the experiment, the mean specific trypsin, amylase and lipase activities of juveniles fed Artemia sp. nauplii were recorded as $0.04 \mathrm{mU} \mathrm{mg} \mathrm{protein}{ }^{-1} \mathrm{~m}^{-1}, 0.114 \mathrm{mg}$ maltose $\mathrm{mg}$ protein ${ }^{-1} \mathrm{~h}^{-1}$ and $9.58 \mathrm{~m}$ Units, respectively, and they were significantly higher than those of juveniles fed trash fish and artificial feed. In the present study it was shown that $O$. marmoratus early juveniles had more efficient digestibility and absorption the nutrient when fed with Artemia.
\end{abstract}

KEYWORDS: Oxyeleotris marmoratus, juvenile, types of feed, growth, digestive enzyme activity

\section{INTRODUCTION}

Asia regions play an important role in aquaculture in the present time as well as future potential. They had the highest aquaculture production, which was $92 \%$ of the total global aquaculture production in 2004. Major freshwater species cultured in this region are carps, tilapias, and catfishes (FAO, 2006). This situation has led to the search for another promising candidate species for enhancement of production in these regions. Among possible candidate species, the marble goby, Oxyeleotris marmoratus has become one of the most attractive candidates as aquaculture is diversified (Senoo et al., 1994a; Amornsakun et al., 2003; Loung et al., 2005).

Oxyeleotris marmoratus is the largest freshwater gobioid fish which belongs to fam- ily Eleotridae and the most expensive freshwater fish in Southeast Asian countries (Axelrod \& Schultz, 1955; Mohsin \& Ambak, 1983). Recently, the production of $O$. marmoratus is very low as $0.1 \%$ from the total of aquaculture production in these regions (FAO, 2006). The main constrain for culture of this fish is provision of the seed, and aquacultures are still mainly dependent on collected wild juvenile because the stable mass seed production technique has not yet been established due to high mortality occurring at the early juvenile stage (Tavarutmaneegul \& Lin, 1988; Senoo et al., 1994b).

The aquaculture production depends greatly on the ability of successful rearing throughout the early life stages. Suitable nutrition is one of the principal factors influenc-

*) Borneo Marine Research Institute, Universiti Malaysia Sabah, Locked Bag, Malaysia 
ing fish survival and depends on the effective ingestion, digestion and assimilation of diets containing the required essential nutrients. In natural condition, crustacean planktonic organisms are the important preys of $O$. marmoratus larvae and juveniles (Mohsin \& Ambak, 1983; Senoo et al., 1993). Zooplankton is usually used as general feed in most of organism cultures (Hecht \& Appelbaum, 1987). For instance, Artemia as suitable feed for $C$. gariepinus larvae (Hogendoorn, 1980), and Cromileptes altivelis (Sugama et al., 2001). Beside that, artificial feed and trash fish were also used as feed for fish larvae and juveniles (Le, 1996; Millamena \& Toledo, 2004; Williams \& Rimmer, 2005).

The results of our previous experiment showed that $10 \mathrm{ppt}$ (brackishwater) can improve the survival and growth of $O$. marmoratus early juveniles from 40 to $100 \mathrm{~d}$ $\mathrm{AH}$. These findings have contributed to solve one of the immense problems in juvenile production, especially from a view point of environmental factors. The cultivation technology of this species is still at early stage and considerable further works are necessary to realize its large aquaculture potential.

In relation to types of feed, studies on the fish digestive enzymes which stress the mechanisms and the best use of nutrients are of unquestionable importance as a background for the optimization of fish feeding procedures (Sua'rez et al., 1995). Basically, digestive enzymes are concerned with the fish biochemical capacity for transforming the feed. Furthermore, the extensions of such studies show the role of many other factors in this process, for example, type of feeding (Jona's et al., 1983) and diet composition (Deguara et al., 2003). From the digestive-enzyme ontogenetic profile it is possible to predict the ability of the species to use many different nutrients (Hofer $\&$ Ko'ck, 1989). Such an adaptive characteristic of these enzymes can be successfully used to take advantage of the nutrient content of diets (Moraes \& Bidinotto, 2000).

There is no study on the type of feed required during the early juvenile stage of $O$. marmoratus. The suitable types of feed at different stages can improve growth and survival rates. In larval stage, Senoo et al. (1993) reported that the combination of Brachionus sp., green water, Moina sp. and artificial feed can increase the survival of $O$. marmoratus larvae. Tavarutmaneegul \& Lin (1988) also men- tioned that Brachionus sp. is very important in larval stage. To improve the rearing techniques of $O$. marmoratus juveniles, studies on types of feed in brackishwater system seem to be necessary. Relationship between the digestive enzymes of juveniles and types of feed, and their effects on growth and survival will give us further knowledge on feed suitability. The objective of this study is to determine the suitable type of feed on growth, survival and digestive enzyme activity of 0 . marmoratus juveniles.

\section{MATERIALS AND METHODS}

\section{Brood Fish and Egg Incubation}

Oxyeleotris marmoratus brood fish were collected from wild freshwater in Sabah, Malaysia and were adapted to captive conditions during a year in 1 tonne fibre tank in Hatchery of Borneo Marine Research Institute, Universiti Malaysia Sabah (UMS Hatchery), Kota Kinabalu, Sabah, Malaysia. Trash fish with liver cod oil enrichment were provided daily as the primary food source. The eggs were obtained from a pair of brood fish by naturally spawned under artificial condition (Senoo et al., 1993) during the period from January 2008 through March 2008. The eggs were then incubated in $700 \mathrm{~L}$ spawning glass aquaria at 28.5 to $30.5^{\circ} \mathrm{C}$. The larvae of 1 day after hatching $(\mathrm{d} \mathrm{AH})$ were transferred into a 1 tonne tank at 10 ppt.

\section{Larval Rearing}

Larval rearing was carried out in brackishwater (10 ppt) system and stocked at density of 100 individuals $L^{-1}$. The larvae were fed rotifers (Brachionus plicatilis) cultured with Nannochloropsis sp. from $3 \mathrm{~d} \mathrm{AH}$, brine shrimp (Artemia sp.) nauplii from 15 to $40 \mathrm{~d}$ AH (Senoo, 2003). Green water (Chlorella sp.) from tilapia culture in brackishwater was maintained of 1.5 $\times 10^{6}$ cells $\mathrm{mL}^{-1}$ in the larval rearing tank. Onset from 30 to $40 \mathrm{~d} \mathrm{AH}$, the larvae were adaptive to eat all the types of feed used in this experiment.

\section{Juvenile Selection and Types of Feed}

Nine glass aquaria $(60 \mathrm{~cm} \times 35 \mathrm{~cm} \times 40 \mathrm{~cm})$ were used and filled with 70 litre of $10 \mathrm{ppt}$ water. The stocking density on this experiment was 100 juveniles aquaria-1. A total of 900 pcs of $40 \mathrm{~d}$ AH juvenile $O$. marmoratus were fed different types of feed. The types of feed in 
this experiment were trash fish (TF), artificial feed (AF), and Artemia sp. (AS) nauplii. This experiment was conducted in triplicate. Artemia cysts brand 'Lucky Artemia O.S.I', (Ocean Star International, Inc., Snowville UT 84336, USA) were used in this experiment. Clean seawater with salinity of $25 \mathrm{ppt}$ was used to hatch the Artemia cyst. Trash fish were bought from the fish market in Kota Kinabalu and kept in freezer to maintain the quality. Head, caudal fin and bones of fish were removed. The clean fish were then cut into small pieces suitable for $O$. marmoratus juvenile feeding. Cargill Nutrition Marine Finfish, Cargill Feed SDN. BHD, Malaysia was used as artificial feed in this experiment. The granule diet must be incised into smaller size suitable for $O$. marmoratus juvenile feeding.

\section{Observation on Growth and Survival Rate}

Specific growth rate (SGR) of O. marmoratus was determined according to the following equation:

$$
\frac{\left(\ln W_{t}-\ln W_{o}\right)}{t \times 100}
$$

where $\ln W_{t}$ and $\ln W_{o}$ are the natural logarithms of final and initial weights, respectively, and $t$ is the period of measurement in days. The survival rate was calculated at the end of experiment as ratio of final to initial number of juveniles.

\section{Sampling Procedure and Digestive Enzyme Assay}

For analysis of digestive enzyme activity, ten juveniles per treatment were sampled randomly at the end of the experiment. The juveniles were properly washed and kept in airtight container and put in a $-80^{\circ} \mathrm{C}$ deep freezer until analysis. Fish tissues were homogenized in ice-cold distilled water using a motor homogenizer for 3 minutes at $4,000 \mathrm{rpm}$. The tissues were then centrifuged using Eppendorf centrifuge at $10.000 \times \mathrm{g}$ for 15 minutes at $4^{\circ} \mathrm{C}$. The supernatant was then stored at $-20^{\circ} \mathrm{C}$ prior to analysis.

Trypsin activity of $O$. marmoratus juveniles was assayed using $N$-benzoyl-DL-arginine 4-nitroanilide hydrochloride (BAPNA) and dimethyl sulfoxide (DMSO) as substrate (Erlanger et al., 1961). The absorbance of the resulting mixture was measured using spectrophotometer Genesys TM 10 UV Series at 410 $\mathrm{nm}$. The trypsin activities were expressed in units (U), as BAPNA unit $\mathrm{mg}$ protein ${ }^{-1}$ using the following formula (Erlanger et al., 1961):

$$
\frac{\text { abs va } \times 1,000 \times \text { vol react mix }}{8,800 \times \text { mg protein in the assay }}
$$

where: abs va is absorbance value at $410 \mathrm{~nm} /$ min, vol react mix is volume of reaction mixture, 8800 is the extinction coefficient of $p$ nitroalinin

Amylase activity was estimated using starch solution (Riedel-de Haen) as substrate as described by Worhington (1993). The activity was evaluated using starch solution in sodium phosphate buffer $\mathrm{pH}$ 6.9. This was followed by addition of 3,5 dinitrosalicylic acid (DNS, Sigma) and kept in boiling water bath for $5 \mathrm{~min}$. The activities were recorded at wave length of $540 \mathrm{~nm}$. The standard solution was prepared by diluted $100 \mathrm{mg}$ maltose in $100 \mathrm{~mL}$ distilled water. The specific amylase activity was expressed as mg maltose $\mathrm{mg}_{\text {protein }}{ }^{-1} \mathrm{~h}^{1}$ at $37^{\circ} \mathrm{C}$. Specific enzyme activity $(\mathrm{U})$ was calculated as below,

Lipase activity was determined by the procedure of Borlongan (1990). The lipase activity was assayed base on measurement of fatty acids released by enzymatic hydrolysis in stabilized emulsion of olive oil (Fluka). The mixture was titrated with $0.01 \mathrm{~N} \mathrm{NaOH}$ using $0.9 \%$ (W/V) thymolphthaleine (Riedel-de Haen) in ethanol as indicator. The thymolphthaleine was added as 2 drops for titration until the appearance of colour changes. A unit of lipase activity $(\mathrm{U})$ was defined as the volume of $0.01 \mathrm{~N}$ $\mathrm{NaOH}$ required neutralizing the fatty acids released during the 6 -h incubation with the substrate and after correction by the appropriate blank.

The total protein content was measured following Lowery et al. (1951) method as described by Dawes (1981). Bovine serum albumen (BSA) was used as standard for determination of body protein content.

\section{Statistical Analysis}

A one-way ANOVA (SPSS version 1.3) was used for statistical evaluation. Means were analyzed using Student-Newman-Keuls (SNK) test. Significance was accepted at $P<0.05$. 


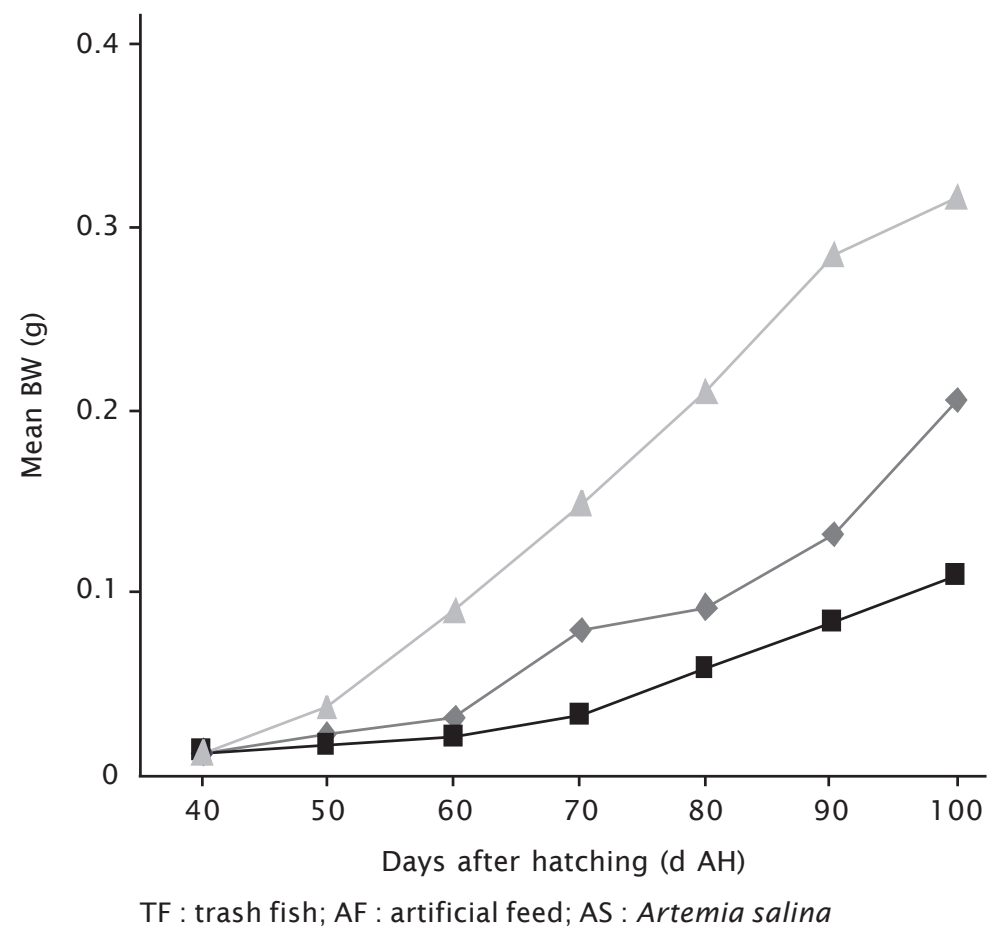

Figure 1. Changes of growth in body weight (BW) of O. marmoratus early juveniles in different types of feed during the experiment

\section{RESULTS}

\section{Growth and Survival Rate of $O$. marmoratus Juveniles}

Growth changes (BW) of O. marmoratus juveniles at different types of feeds were shown in Fig. 1. The mean BW was $0.32 \pm 0.02$ $\mathrm{g}$, the highest in juveniles fed AS and $0.11 \pm$ $0.00 \mathrm{~g}$, the lowest in juveniles fed AF (Figure 2). Specific growth rates (SGR) of $O$. marmoratus juveniles at different types of feeds were also shown in Figure 2. The mean SGR was $5.32 \pm 0.04$, the highest in juveniles fed AS and $3.53 \pm 0.08$ the lowest in juveniles fed AF. Mean SGR in juveniles fed AS showed significantly higher than that of juveniles fed TF and AF. Subsequently, SGR of juveniles fed TF $(4.60 \pm 0.06)$ was significantly higher $(P<0.05)$ than that of juveniles fed AF (Figure 2).

The mean survival rates of juveniles ranged between $41.3 \pm 3.2 \%$, the lowest in juveniles fed $A F$ and $91.3 \pm 2.1 \%$, the highest in juveniles fed AS. The mean survival rate of juveniles fed AS was significantly higher $(P<0.05)$ than those in the other types of feed. The mean survival rate of juveniles fed TF $(76 \pm 3.6 \%)$ was significantly higher $(P<0.05)$ than that of juveniles fed AF (Figure 3 ).

\section{Digestive Enzyme Activities}

The mean specific trypsin activities of juveniles fed $T F, A F$ and $A S$ were recorded as $0.021 \pm 0.002,0.010 \pm 0.002$, and $0.040 \pm 0.000$ $\mathrm{mU}$ mg protein ${ }^{-1} \mathrm{~h}^{-1}$ (mean $\pm \mathrm{SE}$ ), respectively. The specific trypsin activity of juveniles fed AS was significantly higher $(P<0.05)$ than those found in juveniles fed TF and AF. Specific trypsin activity of juveniles fed TF was significantly higher than that of juveniles fed of $A F$ (Figure 4A).

The mean specific amylase activities of juveniles fed TF, AF and AS were recorded as $0.019 \pm 0.003,0.057 \pm 0.007$, and $0.114 \pm 0.005$ mg maltose mg protein ${ }^{-1} \mathrm{~h}^{-1}$ (mean $\pm \mathrm{SE}$ ), respectively. The specific amylase activity of juveniles fed AS was significantly higher $(P<0.05)$ than those found in juveniles fed TF and AF. Specific amylase activity of juveniles fed TF was significantly higher $(P<0.05)$ than that of juveniles fed AF (Figure 4A). 


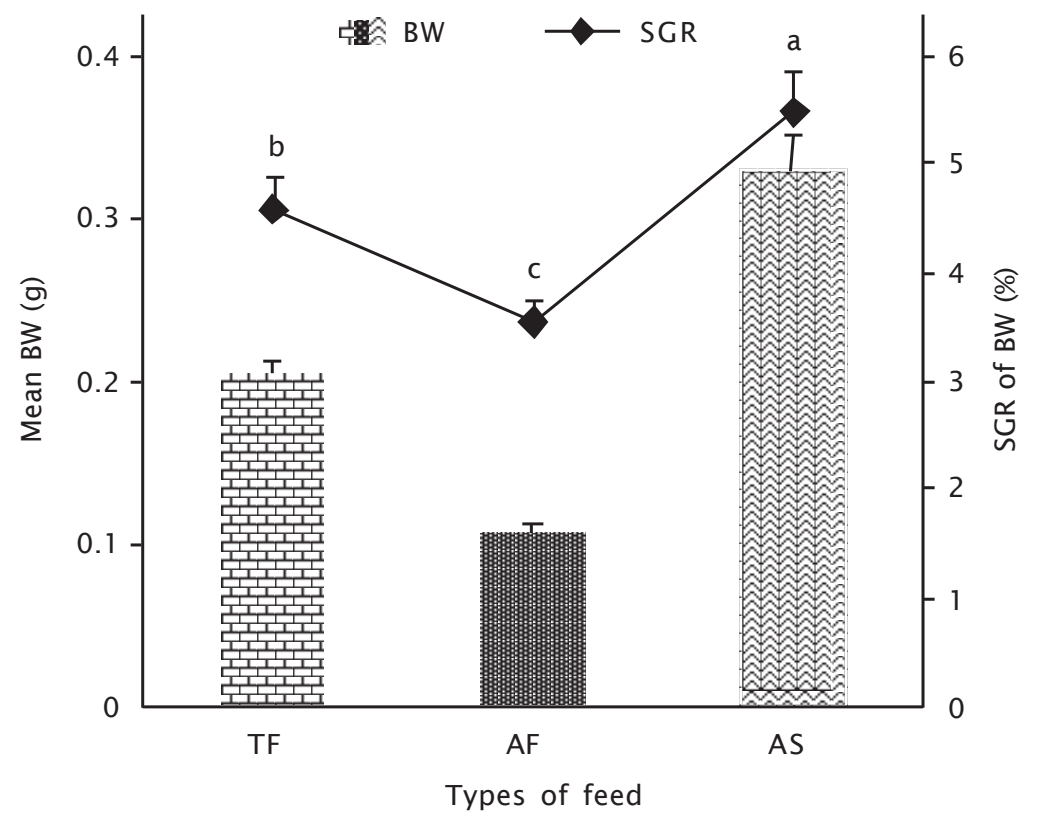

Figure 2. Comparison of mean body weight (BW) (bar graph) and specific growth rate of BW (line) among different types of feed at the end of the experiment. Vertical line indicates SD $(n=3)$. Sub-indices over the bar graph and line denote significant difference (Student-Newman-Keuls (SNK) multiple range test, $(\mathrm{P}<0.05)$

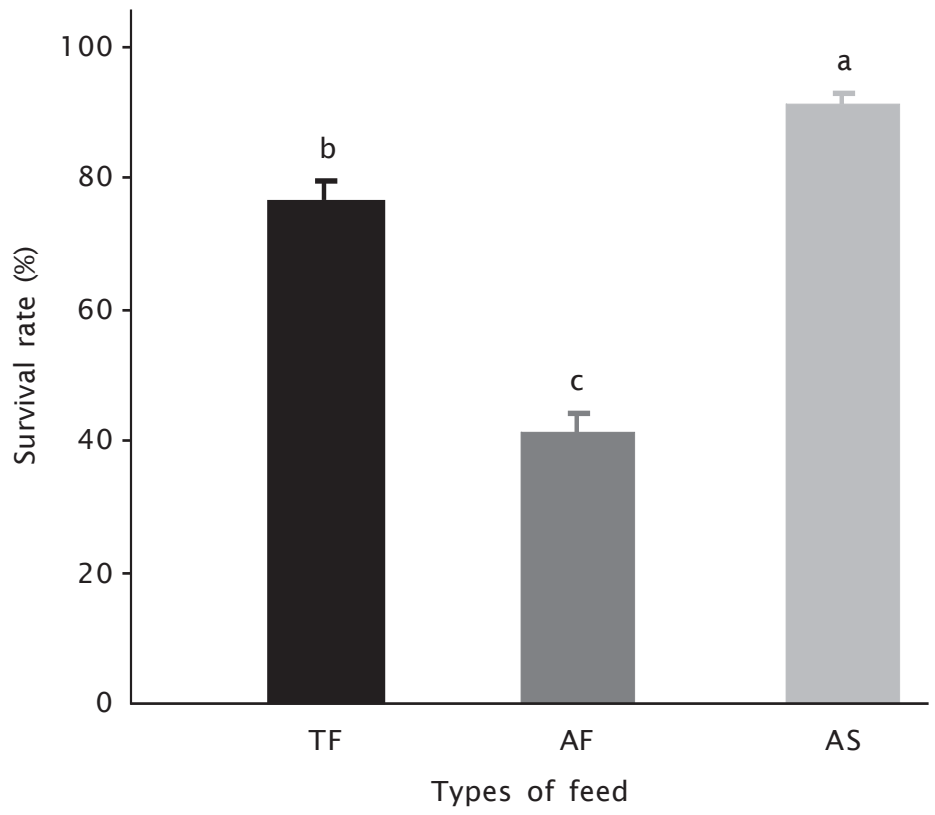

Figure 3. Comparison of survival rate of $O$. marmoratus juveniles among different types of feed. Vertical line indicates SD $(n=3)$. Sub-indices over the bar graph denote significant difference (Student Newman Kull (SNK) multiple range test, $(P<0.05)$ 

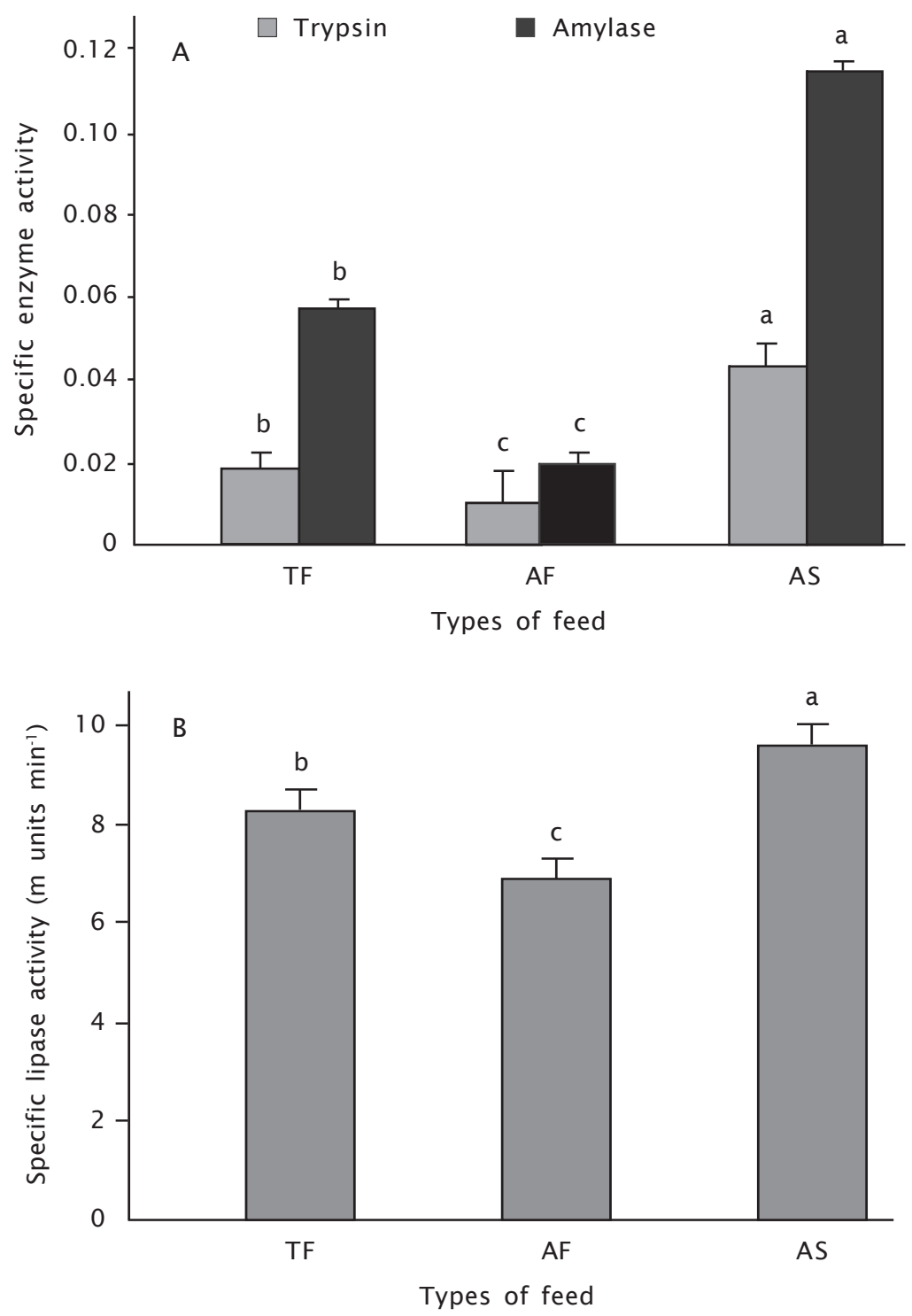

Figure 4. Enzyme activities of $O$. marmoratus juveniles fed with different types of feed (A): Specific trypsin and amylase activities and (B): Specific lipase activity. Vertical line indicates mean $\pm S D(n=3)$. Sub-indices over the bar graph denote significant difference (Student-Newman-Keuls (SNK) multiple range test, $(P<0.05)$

The mean specific lipase activities of juveniles fed TF, AF, and AS were recorded as 8.29 $\pm 0.11,6.87 \pm 0.45$, and $9.58 \pm 0.06$ mUnits (mean $\pm \mathrm{SE}$ ), respectively. The specific lipase activity of juveniles fed AS was significantly higher $(P<0.05)$ than those found in juveniles fed TF and AF. Specific lipase activity of juveniles fed TF was significantly higher $(P<0.05)$ than that of juveniles fed AF (Figure 4B).

\section{DISCUSSION}

\section{Growth and Survival Rate}

Juveniles of $O$. marmoratus fed Artemia had higher growth and survival rates than those of juveniles fed trash fish and artificial feed in the present study. This is possibly due to the nutritional contents in Artemia were optimal 
compared to the other feeds. Although in the present study the nutritional contents have not been determined, but Garcia-Ortega et al. (2001) reported that the nutritional contents of Artemia was protein (55.8\%), lipid (11.2\%), carbohydrate (6.9\%), and ash (5.9\%). Compared to the other feeds, trash fish had protein (14.9\% to $18.7 \%$ ), lipid (15.2\%), and ash (6.5\%) (Barclay $\&$ Williams, 2000), meanwhile artificial feed used in the present study contained protein ( $38 \%$ to $40 \%)$, lipid (3\%), moisture (13\%), and fiber (6\%).

Another explanation is that the juveniles were more attracted in consuming live feed Artemia compared to the other feeds. Artemia nauplii are standard larval fish diet after the rotifer-feeding phase for almost all the marine fish species (Van Stappen, 1996). In freshwater ornamental fish culture, Artemia nauplii are used as intermediate feed for larvae when Moina sp. is too big to ingest by the larvae. The use of Artemia nauplii has been demonstrated in previous study on the culture of fry and adults of the guppy Poecilia reticulate. The results showed that the growth performance of the guppy fry and adults fed Artemia nauplii for 4 weeks were significantly better than fed Moina sp. (Lim et al., 2002)

It is evident that using Artemia for better fish growth and survival rate is more effective than that of trash fish and artificial diet in $O$. marmoratus early juveniles. This phenomenon is perhaps due to the active movement of Artemia. Live feed organisms are thought to stimulate larval feeding by their movement and metabolic wastes and chemical attractants (Kolkovski, 2001). Moreover, live feed organisms are more easily digested than microdiets, and contribute to the digestive process by providing exogenous enzymes (Dhert et al., 1993).

Juveniles fed trash fish showed significantly higher growth and survival rates compared to the juveniles consumed artificial feed. This suggests that juvenile $O$. marmoratus may be attractive with smell of trash fish than artificial feed. Although the nutrient content of artificial feed was higher than trash fish, the juveniles were more attractive to consuming the trash fish. Furthermore, trash fish was fresh compared to artificial diet (William \& Rimer, 2005).

The poor acceptability of artificial feed by O. marmoratus early juveniles was observed. Low growth and high mortality of $O$. marmoratus juveniles associated with feed- ing on artificial diet was also reported by Pham (2001) who reported this was because of its poor attractiveness to $O$. marmoratus. This also occurred in the present study, the large amount of artificial feeds remained on the bottom. It seems to be probable that in this stage, the juveniles still can not fully receive the artificial feed, particularly when they sank on the bottom. Differ from the other species, $O$. marmoratus has a slow growth potential (Mohsin \& Ambak, 1983) and early-stage juveniles mostly prefer to consume the live feed (Senoo et al., 1993b).

Bundit (2007) suggested that poor growth and survival rate associated with artificial feed are caused by low digestibility for protein in O. marmoratus. Similar results were also found in Cromileptes altivelis (Laining et al., 2003) and bullfrog Rana catesbeiana (Secco et al., 2005). Besides, the low feed intake of juveniles fed artificial diet may be due to the limited palatability of diet Joachim \& Felicitas, 2000). Additionally, unsuitability of diet may have resulted in poor acceptability, low feed intake and growth depression in $O$. marmoratus (Bundit, 2007).

Low survival rates of juveniles fed trash fish and artificial feed may be due to more frequent cannibalism. Based on visual observation, the juveniles attacked occasionally the other fish which wold be finally killed. The cannibalism occurred when the juveniles were not attractive to consume the fed. Cannibalistic behaviour is recognized as common in $O$. marmoratus since larval stage and continued until the juvenile stage (Anusorn \& Sujittra, 1989). Bundit (2007) suggested that cannibalism of $O$. marmoratus juveniles can be prevented by being given suitable feed and reducing the stocking density.

\section{Digestive Enzyme Activity}

Changes of type, source and amount of nutrients can alter either the digestive enzyme profile or the concentrations of the enzymes. Such an adaptive characteristic of these enzymes can be successfully used to take advantage of the nutrient content of diets (Moraes \& Bidinotto, 2000). The best use of dietary nutrients can be reflected in the metabolite concentration of the many body compartments, which should alter the metabolic profile. Metabolism is a viable tool to analyze the interrelationship between the digestive biochemical process and the organism out- 
come (Correa et al., 1998; Moraes \& Bidinotto, 2000).

In the present study, the juveniles were reared in $10 \mathrm{ppt}$ salinity and fed different types of feed in order to compare the digestive enzyme activities. Trypsin activity was higher in juveniles consumed Artemia compared to the other types of feed in the present study. The result agreed with Abi-Ayad \& Kestemont (1994) that the activity of fish feed Artemia caused fish consumed higher than that fish fed artificial feed in goldfish larvae. Possible reason of the higher activity could be that Artemia nauplii increased trypsin secretion. Another explanation could be that the ingestion rate of juveniles fed Artemia is higher (Bolassina et al., 2006). Considering the effects of exogenous enzymes from Artemia, the estimated fraction of the enzyme activity was determined to be relatively small compared with total enzyme activity in the juveniles (Bolassina et al., 2006). The major part of total enzyme activity is synthesized by the juvenile as a reaction to physical stimulation due to food ingestion (Hjelmeland et al., 1988; Ueberchar, 1995).

The differences of trypsin activity among three different types of feed in this study might be due to the protein metabolism. Artemia more activated trypsin compared to trash fish and artificial feed. Based on the result of present study, it is possible to speculate that Artemia may also have influenced the activity of digestive enzymes in the juveniles. Speculated that protein in Artemia could be digested easily only by trypsin, but in artificial feed and trash fish need trypsin and other enzyme to digest protein in that feed. The present study indicated that the different activities of trypsin are influenced by the types of feed. Then, trypsin activities may influence digestion and absorption of dietary protein.

Amylase activity of juveniles fed Artemia was higher than the other types of feed. The high amylase activity in the present study may indicate that carbohydrates are efficient energy for juveniles (Tanaka, 1973; Siebenallar, 1984). An initial decrease in carbohydrate metabolism was reported in freshwater teleosts such as pike, Esox lucius L. and perch, Perca fluvialitis L. (Kuz'mina, 1996) when fed with artificial feed.

Another explanation is that amylase activity of juveniles fed Artemia may have adapted to carbohydrate utilization. Amylase activity can be attributed to the importance of carbohydrate metabolism at the first feeding of carp hybrid (Chakrabarti et al., 2006). Increasing rates of dietary protein also induce amylase activity in rainbow trout, Oncorhynchus mykiss (Plantikow, 1981). In general, it can be explained that the values of amylase activities of the different types of feed demonstrates a potential for carbohydrate digestion. The low values were obtained for artificial feed in conjunction with the unattractive feed and influenced the carbohydrate digestion.

Similarly with trypsin and amylase activities, the present study showed that lipase activity was higher in juveniles fed Artemia than those fed with trash fish and artificial feed. The differences in lipase activity among different foods in the present study may be attributed to the adaptation of the juveniles for better digestion and utilization of dietary lipids, being in agreement with results reported by Munilla-Moran et al. (1990) for larval turbot. The lowest lipase activities in trash fish and artificial feed might be related to feed digestion (De Silva \& Anderson, 1995).

The lowest activities of all enzymes associated with artificial feed indicate less attractiveness of artificial feed. Kolkovski (2001) suggested that poor performance of microdiet is related to inadequate incorporation of nutrients due to poor ingestion, digestion and assimilation. Similar statement on the relatively low level of enzyme activities has been reported as one of the reasons for the limited success of artificial diet and the poor growth of larvae (Dabrowski, 1984; Kolkovski, 2001).

Utilization of artificial diet for early juvenile stage of the present species is considered as still unsuitable. This is supported by findings in some species such as bighead carp, Aristichtys nobilis (Carlos, 1988) and salmon species (Dabrowski, 1984) in which without live food, they have been relatively successful to digest artificial diet due to size and stage of development of the emerging larvae. Another supporting data suggested that weaning to dry diet is done gradually; starting with co-feeding and reducing the amount of live feeds (usually Artemia) until complete replacement with dry diets (Jones et al., 1993). Feeding prey organisms such as Artemia nauplii in a short time before dry diets are offered may increase digestive activity and increase the ability of larvae to digest the dry diets (Kolkovski et al., 
1997). However, results of the present study show that $O$. marmoratus early juveniles have more efficient digestibility and nutrient absorption when Artemia nauplii were supplied. Based on the results of this experiment, gradually decreasing of live feed before changes to dry diets seems to be necessary in order to improve rearing technique of $O$. marmoratus juvenile.

\section{ACKNOWLEDGEMENTS}

We are grateful to Professor Datuk Dr. Kamaruzzaman Haji Ampon, Vice Chancellor, Universiti Malaysia Sabah, Professor Dr. Saleem Mustafa, Director, Borneo Marine Research Institute of Universiti Malaysia Sabah, and Dr. Haji Jusuf Serang Kasim, The Mayor of Tarakan Government, Indonesia for their encouragements and supports. We thank all the staff of Borneo Marine Research Institute Fish Hatchery, Universiti Malaysia Sabah for their cooperation in the experiment.

\section{REFERENCES}

Abi Ayad, A. and P. Kestemont. 1994. Comparison of the Nutritional Status of Goldfish (Carassius auratus) Larva Fed with Live, Mixed or Dry Diet. Aquaculture. 128: 163176.

Amornsakun, T., W. Sriwatana, and U. Chamnanwech. 2002. Some Aspects in Early Life Stage of Sand Goby, Oxyeleotris marmoratus Larvae. Songklanakarin J. Sci.Technol. 24: 611--619.

Anusorn, M. and P. Sujittra. 1989. Nursing on Sand Goby (Oxyeleotris marmoratus) in the Earthen Pond (in Thai). In: Pathum Thani Freshwater Fisheries Station, D.o.F., (eds.). DOF Anual Report. Department of Fisheries, Bangkok, Thailand. p. 99-106.

Appelbaum, S. and P. Van Damme. 1988. The Feasibility of Using Exclusively Artificial Dry Feeding for Rearing of Israeli (Clarias gariepinus Burchell) Larvae and Fry. J. Appl. Ichthyol. 4: 105--110.

Axelrod, H.R. and L.P. Schultz. 1955. Hand Book of Tropical Aquarium Fish. New York: McGraw-Hill.

Barclay, M. and K.C. William. 2000. Inter-Laboratory Nutritional Chemical Calibration. Miscellaneous Report of ACIAR Project FIS/97/ 73. Australian Centre for International Agriculture Research, Canberra, Australia.

Bolasina, S., A. Perez, and Y. Yomashita. 2006. Digestive Enzyme Activity During Ontoge- netic Development and Effect of Starvation in Japanese Flounder, Paralichthys olivaceus. Aquaculture. 250: 503-515.

Borlongan, I.G. 1990. Studies on Digestive Enzyme Lipase of Milkfish, Chanos chanos. Aquaculture. 89: 315-325.

Bundit, J. 2007. The Nutrition and Feeding of a Native Thai Species, The marble goby (Oxyeleotris marmoratus), Involving onFarm and Experimental Studies. Ph.D. Thesis. Institute of Aquaculture, University of Stirling, Scotland. 175 pp.

Carlos, M.H. 1988. Growth and Survival of Bighead Carp Aristichthys nobilis Fry Feed at Different Intake Levels and Feeding Frequencies. Aquaculture. 68: 267-276.

Chakrabarti, R., R.M. Rathore, P. Mittal, and S. Kumar. 2006. Functional Change in Digestive Enzymes and Characterization of Proteases of Silver Carp and Bighead Carp Hybrid, During Early Development. Aquaculture. 253: 694-702.

Corre'a, C.F., P.M. Bidinotto, and G. Moraes. 1998. Comparison of the Amilohydrolytic Activity in the Gut of Neotropical Teleost Species Pacu and Tambaqui Hybrid Submitted to Different Contents of Soluble Carbohydrate. Fish Feeding Ecology and Digestion: GUTSHOP'98, Baltimore USA. http:yywww. fishbiology congress.org.

Dabrowski, K. 1984. The Feeding of Fish Larvae: Present "State of the Art" and Perspectives. Reprod., Nutr. Dev. 24: 807-833.

De Silva, S.S. and Anderson, T.A. 1995. Fish Nutrition in Aquaculture. London: Chapman \& Hall.

Dhert, P. 1991. Bottle-Necks in Larviculture. Improved Use of Artemia in the Larviculture of the Tropical Fish Lates calcarifer (Bloch) and Siganus guttatus (Bloch). Ph.D Thesis. University of Ghent, Gent, Belgium. p. 18--33.

Erlanger, B., N. Kokowsky, and W. Cohen. 1961. The Preparation and Properties of Two New Chromogenic Substrates of Trypsin. Arch. Biochem. Biophys. 95: 271-278.

Food and Agriculture Organization (FAO). 2006. State of world aquaculture. Inland Water Resources and Aquaculture Service Fishery Resources Division Fisheries Department, Food and Agriculture Organization (FAO) of the United Nations. 129 Rome.

Garcia-Ortega, A., E.A. Huisman, P. Sorgeloos, and J. Verreth. 2001. Evaluation of Protein Quality in Microbound Starter Diets Made 
With Decapsulated Cyst of Artemia and Fishmeal for Fish Larvae. J. World Aquacult. Soc. 32: 317-329.

Hecht, T. and S. Appelbaum. 1988. Observation of Inter-Specific Aggression and Coeval Sibling Cannibalism by Larval and Juvenile Clarias gariepinus (Claridae: Pisces) Under Controlled Conditions. J. Zool. Soc. (Lond.). 214: 21--44.

Hjelmeland, K., B.H. Pedersen, and E.M. Nilssen. 1988. Trypsin Content in Intestines of Herring Larvae, Clupea harengus Ingesting Iner Polystyrene Spheres or Live Crustacean Prey. Mar. Biol. 98. 331-335.

Hofer, R. and G. Kock. 1989. Method for Quantitative Determination of Digestive Enzymes in Fish Larvae. Pol. Arch. Hydrobiol. 36: 439--441.

Hogendoorn, H. 1983. Growth and Production of the African Catfish Clarias gariepinus C and V: III. Bioenergetic Relations of Body Weight and Feeding Level. Aquaculture. 35: 1--17.

Joachim, W.H. and P.P. Felicitas. 2000. Handbook on Ingredients for Aquculture Feeds. Dordrecht, The Natherlands.: Kluwer Academics Publishers.

Jones, D.A., M.S. Kamaruddin, and L. Le Vay. 1993. The Potential for Replacement of Live Feeds in Larval Culture. J. World Aquacult. Soc. 24: 199-210.

Jonna, R. and M. Weinheimer. 2003. "Eletoridae" (on-line), Animal Diversity Web. http:// animaldiversity.ummz.umich.edu/site/account/information/eletoridae.htm

Kim, B.G., S. Divakaran, C.L. Brown, and A. Ostrowski. 2001. Comparative Digestive Enzyme Ontogeny in Two Marine Larval Fishes: Pacific Threadfine (Polydactylus sexfilis) and Bluefin Trevally (Caranx melampygus). Fish Physiol. Biochem. 24: 225-241.

Kolkovski, S. 2001. Digestive Enzymes in Fish Larva and Juveniles-Implications and Application of Formulaed Diets. Aquaculture. 200: 181-201.

Kuz'mina, V.V. 1996. Influence of Age on Digestive Enzyme Activity in Some Freshwater Teleosts. Aquaculture. 148: 25-37.

Lim, L.C., Y.L. Cho, P. Dhert, C.C. Wong, N. Nelis, and P. Sorgeloos. 2002. Use of Decapsulated Artemia Cysts in Ornamental Fish Culture. Aquac. Res. 33: 575--589.

Lowry, O.H., N.J. Rosebrough, A.L. Farr, and D.J. Randal. 1951. Protein measurement with
Folin Phenol Reagent. J. Biol. Chem. 193: 265-276.

Luong, V.C., Y. Yang, and C.K. Lin. 2005. Cove Culture of Marble Goby (Oxyeleotris marmonatus Bleeker) and Carps in Tri An Reservoir of Vietnam. Aquaculture. 244: 97-107.

Mohsin, A.K.M. and M.A. Ambak. 1983. Freshwater Fishes of Peninsula Malaysia. Kuala Lumpur: Penerbit Universiti Pertanian Malaysia.

Moraes, G. and P.M. Bidinitto. 2000. Induced Changes in the Amylohydrolytic Profile of the Gut of Piaractus mesopotamicus (Holmberg, 1885) Fed Different Levels of Soluble Carbohydrate: its Correlation with Metabolic Aspects. Rev. Ictiol. 8: 47-51.

Munilla-Moran, R., J.R. Stark, and A. Barbour. 1990. The Role of Exogeneous Enzyme in Digestion in Cultured Torbot Larvae Scophtalmus maximus. Aquaculture. 88: 337-350.

Pham, T.L. 2001. Studies on the Early Development and Larval Rearing of Oxyeleotris marmoratus (Bleeker). M.S. Thesis. Faculty of Science and Technology, Kolej Universiti Terengganu, Universiti Putra Malaysia.

Secco, M.E., D.V.M. Stefani, and M.R. Vidotti. 2005. Apparent Digestibility of Different Ingredients in Diets for Bullfrog Rana catesbeiana Tadpoles. Journal of The World Aquacul. Society. 36: 135--140.

Senoo, S., S.H. Cheah, and K.J. Ang. 1993. Natural Spawning of Marble Goby, Oxyeleotris marmoratus Under Artificial Condition. Malaysia Fishery Society Fishmail. 5(3): 16-18.

Senoo, S., M. Kaneko, S.H. Cheah, and K.J. Ang. 1994a. Egg Development, Hatching, and Larval Development of Marble Goby, Oxyeleotris marmoratus Under Rearing Conditions. Fisheries Science. 60: 1-8.

Senoo, S., K.J. Ang, and G. Kawamura. 1994b. Development of Sense Organs and Mouth and Feeding of Reared Marble Goby Oxyeleotris marmoratus Larvae. Fisheries Science. 60: 361-368.

Siebenallar, J.F. 1984. Analysis of the Biochemical Consequences of Ontogenic Vertical Migration in a Deep-Living Teleost Fish. Physiol. Zool. 57: 598--608.

Suarez, M.D., M.C. Hidalgo, M. Garcia Galego, A. Sanz, and M. De la Higuera. 1995. Influence of the Relative Proportions of The Energy 
Yielding Nutrients on the Liver Intermediary Metabolism of the European Eel. Com. Biochem. Physiol. A 111:421-428.

Sugama, K., Trijoko, B. Slamet, S. Ismi, E. Setiadi, and S. Kawahara. 2001. Manual for Seed Production of Humpback Grouper, Cromileptis altivelis. Bali, Indonesia: Gondol Research Institute for Mariculture \& Japan International Cooperation Agency (IICA).

Tanaka, M. 1973. Studies on the Structure and Functional of the Digestive System of Teleost Larvae. Ph.D. Dissertation. Dept. of Fisheries, Faculty of agriculture, Kyoto University. Japan.

Tavarutmaneegul, P. and C.K. Lin. 1988. Breading and Rearing of Sand Goby (Oxyeleotris marmoratus, BLK). Aquaculture. 69: 299-305.

Ueberschar, B. 1995. The use of Tryptic Enzyme Activity Measurement as a
Nutritional Condition Index. Laboratory Calibration Data and Field Application, ICES. Mar. Sci. Symp. 201: 119--129.

Van Stappen, G. 1996. Artemia. In Lavens, P. and Sorgeloos, P. (Eds.). Manual on the Production and Use of Live Food for Aquaculture. Food and Agriculture Organization (FAO) Fisheries Technical Paper. Rome. 361: 79-106.

Williems, K.C. and M.A. Rimmer. 2005. The Future of Feeds and Feeding of Marine Finfish in The Asia-Pacific Region: The Need to Develop Alternative aquaculture Feeds. Regional Workshop on Low Value and Trash Fish in the Asia-Pacific Region. 7-9 June 2005. Hanoi, Vietnam.

Worthington, V. 1993. Worthington Enzyme Manual. Enzymes and Related Biochemicals. New Jersey, US: Worthington Chemical. 